\title{
Nowa technologia zgrzewania tarciowego rury z pokrywą
}

\section{New friction welding technology of the tube with the cover}

\section{Streszczenie}

W artykule przedstawiono wyniki badań nad zastosowaniem do zgrzewania końcówek rur z pokrywami nowej technologii zgrzewania tarciowego z niezużywającym się narzędziem. Rury i pokrywy wykonane były ze stopu aluminium EN AW 2017A, niespawalnego konwencjonalnymi metodami. Sprawdzono możliwość zgrzewania pokrywy $\mathrm{z}$ rurą metodą FSW oraz nową metodą $\mathrm{z}$ narzędziem o specjalnie wyprofilowanej powierzchni tarcia. Przedstawiono wyniki badań budowy strukturalnej zgrzeiny i wytrzymałości złączy uzyskanych nową techniką.

\section{Wstęp}

Technologia zgrzewania końcówek rur z pokrywami wymaga uwzględnienia wielu czynników związanych z późniejszą eksploatacją złączy oraz szybkością i łatwością wykonywania połączenia. W przypadku zamykania końcówek rur, stanowiących cylinder siłownika, zastosowana technologia musi umożliwiać uzyskiwanie trwałego i wytrzymałego połączenia, zachowującego dużą szczelność przez cały okres eksploatacji siłownika. W przypadku zastosowania materiałów niespawalnych lub trudno spawalnych, wykonywanie tego typu złączy jest zagadnieniem trudnym. Instytut Spawalnictwa podjął się zadania opracowania technologii zgrzewania końcówek rur z pokrywami wykonanymi z wytrzymałego i lekkiego stopu aluminium EN AW 2017A, który - choć bardzo przydatny w wielu zastosowaniach konstrukcyjnych - jest trudno spawalny znanymi metodami spawalniczymi. Zamknięcie rury wymaga zagwarantowania wysokiej jakości połączenia

Dr inż. Adam Pietras, mgr inż. Aleksandra Węglowska, mgr inż. Beata Rams, dr inż. Marek Węglowski - Instytut Spawalnictwa, Gliwice.

\section{Abstract}

Results of the use of the new friction welding technology with non-consumable tool for welding of the tubes with the covers are presented in this paper. Tubes and covers were made from the EN AW 2017A aluminium alloy, which is unweldable with the use of the conventional welding methods. Possibility of application of the FSW technology and of the new method with the use of the tool with a specially profiled friction face was tested during the investigations. Results of the microscopy and the joints strength examination are also presented.

na całej długości pobocznicy rury, uzyskiwanego w powtarzalny sposób w warunkach produkcyjnych. Zastosowanie konwencjonalnego zgrzewania tarciowego elementów rurowych wykonanych z tego materiału nie gwarantuje odpowiedniej jakości złącza. Również techniki spawania łukowego nie zapewniają poprawnego połączenia wzdłuż całego obwodu rury. Korzystając z dotychczasowych doświadczeń zgrzewania metodą FSW różnego rodzaju materiałów, zdecydowano się zastosować tę stosunkowo nową metodę zgrzewania z niezużywającym się narzędziem do

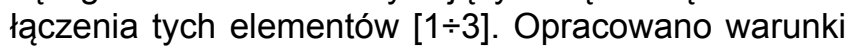
wykonywania połączenia tarciowego odpowiednio dobranym narzędziem FSW oraz metodą, która pozwala na uzyskiwanie połączenia o stałej jakości na całym obwodzie zgrzeiny, bez otworu technologicznego na końcu [4]. Narzędzie do FSW pozostawia na końcu linii zgrzewania otwór technologiczny, który może być wyeliminowany tylko przez przeprowadzenie dodatkowych zabiegów ograniczających płynność produkcji. Opracowanie nowej metody podyktowane było koniecznością ograniczenia lub wyeliminowania tej niedogodności. W ramach badania zgrzewania nową metodą, korzystając z rozwiązania opracowanego w Instytucie Spawalnictwa, przygotowano technologię do jej zastosowania w warunkach produkcyjnych $[5,6]$. 


\section{Stanowisko badawcze i narzędzia do zgrzewania}

Badanie procesu zgrzewania prowadzono na stanowisku do zgrzewania metodą FSW, znajdującym się w Instytucie Spawalnictwa w Gliwicach. W skład stanowiska wchodziły: frezarka konwencjonalna FYF32JU2, unikatowa głowica pomiarowa LowStir, pirometr firmy FLUKE 576 oraz komputer wyposażony w oprogramowanie umożliwiające rejestrację, wizualizację i analizę danych pomiarowych, na bieżąco odczytywanych z przyrządów. Widok stanowiska badawczego przedstawiono na rysunku 1.

Narzędzia do nagrzewania i formowania lica zgrzeiny wykonano ze stali szybkotnącej HS 6-5-2-5. Widok części roboczej narzędzi przedstawiono w tablicy I. Parametry technologiczne zostały dobrane na podstawie dotychczasowych doświadczeń autorów, związanych

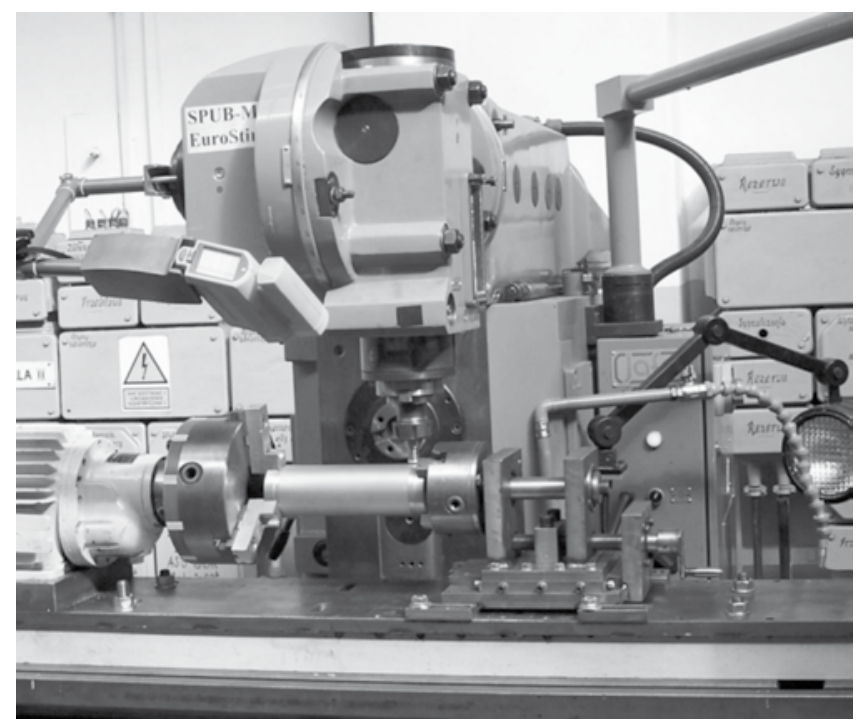

Rys. 1. Stanowisko badawcze

Fig. 1. The welding stand z badaniem procesu FSW i FSP oraz zakresem pracy zgrzewarki (frezarki FYF32JU2).

Pomiary momentu tarcia oraz sił rejestrowano podczas procesu zgrzewania na całym obwodzie z częstotliwością $100 \mathrm{~Hz}$. Wartość średnią momentu obliczano ze 100 punktów pomiarowych, przy czym pod uwagę wzięto jedynie obszar, gdzie nastąpiła pełna stabilizacja procesu.

W celu oceny głębokości oddziaływania narzędzia bez dodatkowego trzpienia w materiał obszaru zgrzewania przeprowadzono badania metalograficzne struktury zgrzein otrzymanych w różnych warunkach procesu. Badania wykonano na mikroskopie świetlnym MEF4M firmy Leica. Zgłady wykonywane były prostopadle do kierunku przesuwu narzędzia w odległości $50 \mathrm{~mm}$ od końca płyty próbnej. Wykorzystując analizator obrazu Omnimet Enterprise ver. 5.4 firmy Buehler, dla każdego z badanych parametrów prowadzenia procesu wykonano pomiary grubości g uplastycznionej i wymieszanej warstwy tworzącej zgrzeinę.

\section{Elementy zgrzewane}

Próby zgrzewania prowadzono na rurach o średnicy zewnętrznej $68 \mathrm{~mm}$ i grubości ścianki $2,5 \mathrm{~mm}$ oraz odpowiednio przygotowanych pokrywach. Elementy wykonano ze stopu aluminium EN AW 2017A. Zastosowany materiał oraz konfiguracja zgrzewanych elementów wymagała specjalnego przygotowania obszaru łączenia. Pokrywa zamykająca rurę została przygotowana w taki sposób, aby rura na całym obwodzie podczas zgrzewania była nasunięta na odpowiednie wybranie pokrywy usztywniającej cały układ łączonych elementów. Odpowiednio uformowana pokrywa stanowiła zarazem podpore uplastycznionych podczas procesu warstw materiału. Elementy przygotowane do zgrzewania przedstawiono na rysunku 2.

Tablica I. Części robocze narzędzi zastosowanych w badaniach

Table I. The view of the working parts of tools used during investigation

\begin{tabular}{|c|c|c|}
\hline Typ narzędzia & Rzut z boku & Widok narzędzia \\
\hline Narzędzie Triflute & Rzut z dołu \\
\hline Narzędzie specjalne & \\
\hline
\end{tabular}




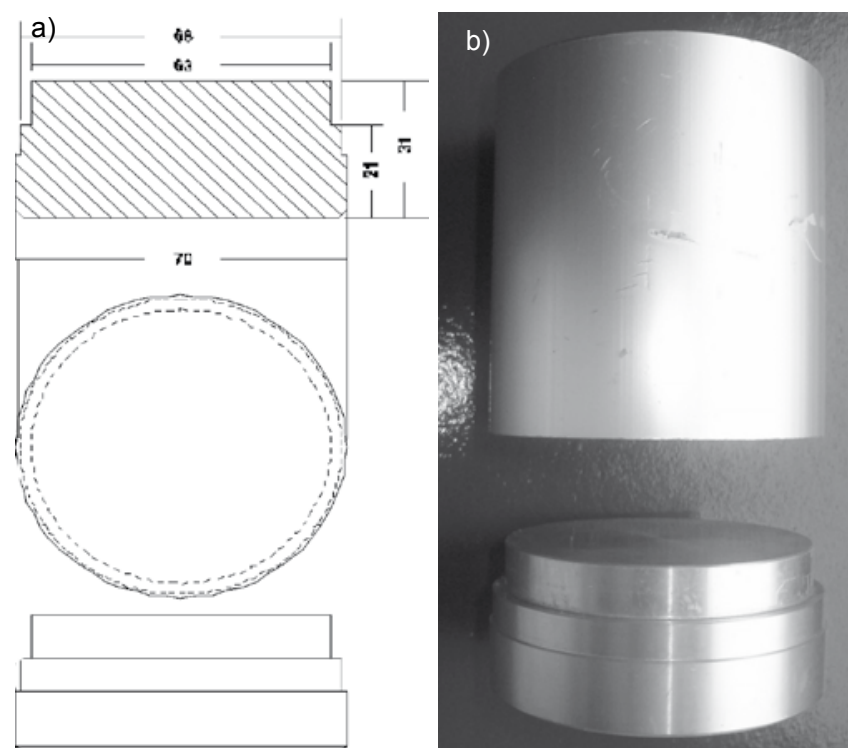

Rys. 2. Elementy przygotowane do łączenia metoda FSW: a) schemat konstrukcji pokrywy, b) widok pokrywy i rury Fig. 2. The view of the elements ready to weld with FSW: a) the scheme of cover construction, b) the view of cover and tube

Tablica II. Skład chemiczny stopu aluminium EN AW 2017A (\% wag.) Table II. Chemical constitution of aluminium alloy EN AW 2017A (weight \%)

\begin{tabular}{|c|c|c|c|c|c|c|c|}
\hline $\mathrm{Si}$ & $\mathrm{Fe}$ & $\mathrm{Cu}$ & $\mathrm{Mn}$ & $\mathrm{Mg}$ & $\mathrm{Cr}$ & $\mathrm{Zn}$ & $\mathrm{Al}$ \\
\hline $0,2 \div 0,8$ & 0,7 & $3,5 \div 4,5$ & $0,4 \div 1,0$ & $0,4 \div 1,0$ & 0,1 & 0,25 & reszta \\
\hline
\end{tabular}

Skład chemiczny stopu, z jakiego wykonano zgrzewane elementy, zestawiono $\mathrm{w}$ tablicy II. Jest to stop utwardzony przez naturalne utwardzanie wydzieleniowe. Wykazuje dużą skłonność do pęknięć podczas procesów spawalniczych, stąd też uważany jest za niespawalny.

W pracy badano oddziaływanie narzędzia bez trzpienia na proces zgrzewania. Do badań wykorzystano blachy o grubości $2,5 \mathrm{~mm}$, wykonane $z$ tych samych materiałów co rury i pokrywy. Badanie procesu tworzenia zgrzeiny $w$ tym układzie prowadzono przy tym samym zakresie parametrów, jak przy zgrzewaniu rur.

\section{Badanie procesu zgrzewania elementów rurowych metodą FSW}

Opracowanie najbardziej korzystnej technologii zgrzewania rury z pokrywą rozpoczęto od sprawdzenia możliwości zgrzewania ww. elementów metodą FSW. Rury i pokrywy montowano na odpowiednim stanowisku (rys. 1) i prowadzono proces zgrzewania z wykorzystaniem narzędzia Triflute (tabl. I). Proces zgrzewania prowadzono przy prędkości zgrzewania $200 \div 700 \mathrm{~mm} / \mathrm{min}$, i różnych prędkościach obrotowych narzędzia. Badania
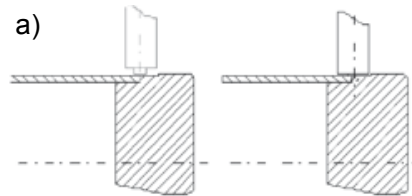

b)

Rys. 3. Schemat ustawienia narzędzia z trzpieniem względem styku rura-pokrywa podczas zgrzewania: a) trzpień narzędzia umieszczony w miejscu styku dwóch elementów, b) krawędź trzpienia narzędzia umieszczona w styku dwóch elementów

Fig. 3. Scheme of tool setting with pin in relation to the pipe-cover contact during the welding process: a) pin set in the pipe-cover contact, b) edge of pin set in the pipe-cover contact
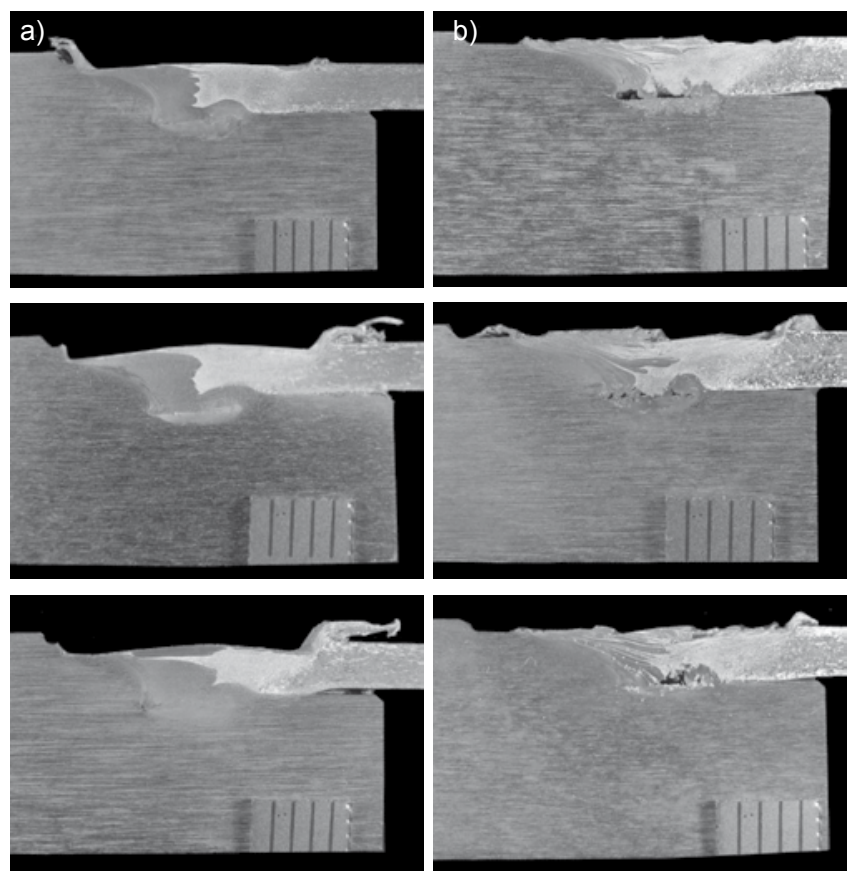

Rys. 4. Struktura zgrzeiny uzyskana z zastosowaniem narzędzia Triflute. Prędkość obrotowa narzędzia, od lewej: 450, 560 i 710 obr/min, prędkość zgrzewania: $430 \mathrm{~mm} / \mathrm{min}$. W czasie zgrzewania elementy wykonały 1 obrót: a) trzpień narzędzia umieszczony w miejscu styku dwóch elementów (wg rys. 3a), b) krawędź trzpienia narzędzia umieszczona w styku dwóch elementów (wg rys. 3b)

Fig. 4. Structure of weld obtained with the use of a Triflute tool. Rotational speed of tool, from the left side: 450,560 i $710 \mathrm{rpm}$, welding speed: $430 \mathrm{~mm} / \mathrm{min}$. During the welding process elements executed one revolution: a) pin set in the pipe-cover contact (fig. 3a), b) edge of pin set in the pipe-cover contact (fig. 3b)

zgrzewania elementów przeprowadzono dla różnych układów narzędzie-element. Schematy ustawienia narzędzia względem elementów zgrzewanych przedstawiono na rysunku 3. Poszukiwano takiego ustawienia narzędzia, które zagwarantuje tworzenie powtarzalnej zgrzeiny o odpowiedniej budowie strukturalnej. Wybrane wyniki badań budowy strukturalnej uzyskanych zgrzein przedstawiono na rysunku 4.

$Z$ badań wynika, że w przypadku usytuowania trzpienia narzędzia w styku łączonych elementów uzyskiwano zwartą strukturę zgrzeiny o prawidłowej budowie. W przypadku ustawienia trzpienia narzędzia na krawędzi styku elementów jakość zgrzeiny była niezadowalająca, bez względu na zastosowane prędkości obrotowe 
narzędzia. W przypadku zastosowania podczas procesu zgrzewania narzędzia z trzpieniem, po jego wycofaniu na końcu linii zgrzewania pozostawał otwór technologiczny, który może stanowić znaczącą niedogodność przy planowanym wykorzystaniu tej technologii w warunkach produkcyjnego zamykania rur.

\section{Badanie procesu zgrzewania płaskich blach narzędziem specjalnym}

Proces zgrzewania elementów rurowych narzędziem z trzpieniem, przygotowanym jak do typowego procesu FSW, przebiegał poprawnie, lecz na końcu linii zgrzewania pozostawał otwór technologiczny. W celu jego wyeliminowania sprawdzono możliwość uzyskiwania użytecznej zgrzeiny, wykorzystując w celu nagrzania i uplastycznienia materiału w obszarze styku narzędzie bez trzpienia, ze specjalnie uformowaną powierzchnią roboczą, jak w tablicy I. Podczas wykonywania złączy zastosowano różne zestawy parametrów zgrzewania. Pozwoliło to na określenie wpływu prędkości obrotowej narzędzia oraz prędkości liniowej na głębokość oddziaływania wieńca narzędzia na zgrzewane elementy oraz na jakość złączy. Badania procesu zgrzewania prowadzono z prędkością liniową zgrzewania (posuwu): 280, 450 i 560 mm/min. Prędkości obrotowe narzędzia wynosiły dla każdego posuwu: 450, 560, 710, 900 i 1120 obr/min. Dodatkowo dla posuwu $280 \mathrm{~mm} / \mathrm{min}$ zastosowano niższe prędkości obrotowe narzędzia: 280 oraz 355 obr/min. Schemat prowadzenia procesu pokazano na rysunku 5. Przykładowe makrostruktury uzyskanych zgrzein przedstawiają rysunki 6 i 7.

Przebieg zmian grubości zgrzeiny g oraz uzyskiwanych wytrzymałości zgrzein $\mathrm{R}_{\mathrm{m}}$, aproksymowanych odpowiednimi funkcjami, przedstawiono na rysunku 8. $Z$ badań wynika, że dla stosunkowo niewielkiej prędkości obrotowej narzędzia grubość czynna zgrzeiny g jest stosunkowo wysoka i sięga prawie grubości zgrzewanych blach. Wraz ze wzrostem prędkości obrotowej narzędzia grubość zgrzeiny gwałtownie spada. Ze zmianą grubości zgrzeiny zmienia się wytrzymałość złączy. Największą wytrzymałością charakteryzują się złącza wykonane przy niskiej prędkości obrotowej narzędzia, natomiast przy wysokich prędkościach zgrzewania i wysokich prędkościach obrotowych narzędzia wytrzymałość złączy jest bardzo niska.
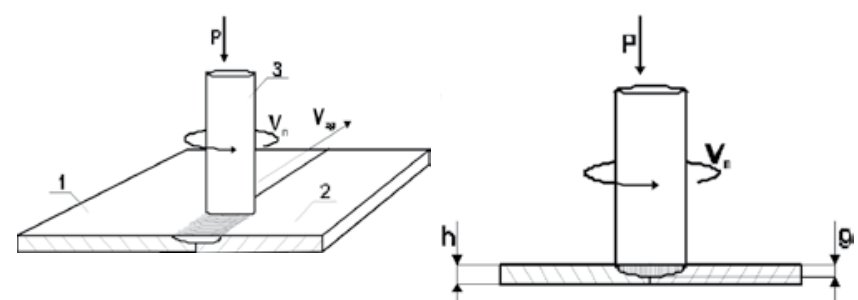

Rys. 5. Schemat procesu zgrzewania z narzędziem specjalnym i zaznaczona grubość zgrzeiny g; 1, 2 - zgrzewane blachy; 3 - narzędzie; $\mathrm{P}$ - siła docisku narzędzia; $\mathrm{v}_{\mathrm{n}}$ - prędkość obrotowa, obr/min; $\mathrm{v}_{\mathrm{zg}}$ - prędkość zgrzewania, $\mathrm{mm} / \mathrm{min}$

Fig. 5. Scheme of the welding process with a special tool, with mark thickness of weld g; 1, 2- welded sheets; 3 - tool; $\mathrm{P}$ - weld force; $\mathrm{v}_{\mathrm{n}}$ - rotational speed, $\mathrm{rpm} ; \mathrm{v}_{\mathrm{zg}}$ - welding speed, $\mathrm{mm} / \mathrm{min}$

Rys. 6. Makrostruktura zgrzeiny. Parametry zgrzewania: $\mathrm{v}_{\mathrm{n}}=355 \mathrm{obr} / \mathrm{min}, \mathrm{v}_{\mathrm{zg}}=280 \mathrm{~mm} / \mathrm{min}$

Fig. 6. Macrostructure of weld. Welding parameters: $v_{n}=355 \mathrm{rpm}$, $\mathrm{v}_{\mathrm{zg}}=280 \mathrm{~mm} / \mathrm{min}$

Rys. 7. Makrostruktura zgrzeiny. Parametry zgrzewania: $\mathrm{v}_{\mathrm{n}}=710 \mathrm{obr} / \mathrm{min}, \mathrm{v}_{\mathrm{zg}}=280 \mathrm{~mm} / \mathrm{min}$

Fig. 7. Macrostructure of weld. Welding parameters: $v_{n}=710 \mathrm{rpm}$, $\mathrm{v}_{\mathrm{zg}}=280 \mathrm{~mm} / \mathrm{min}$
Tablica III. Zestawienie danych dotyczących głębokości zgrzewania w zależności od zastosowanych parametrów zgrzewania

Table III. Statement of data concerning of the thickness of weld in dependence on the used welding parameters

\begin{tabular}{|c|c|c|c|}
\hline \multicolumn{2}{|c|}{ Parametry zgrzewania } & \multirow{2}{*}{$\begin{array}{c}\text { Grubość } \\
\text { zgrzeiny } \\
\mathrm{g}, \mathrm{mm}\end{array}$} & \multirow{2}{*}{$\begin{array}{c}\text { Wytrzyma- } \\
\text { łość na roz- } \\
\text { ciąganie } R_{m} \\
\mathrm{MPa}\end{array}$} \\
\hline $\begin{array}{l}\text { Prędkość obrotowa } \\
v_{n} \text {, obr/min }\end{array}$ & $\begin{array}{l}\text { Prędkość linio- } \\
\text { wa } v_{\mathrm{zg}}, \mathrm{mm} / \mathrm{min}\end{array}$ & & \\
\hline 280 & \multirow{7}{*}{280} & 1,9 & 240,12 \\
\hline 355 & & 2,0 & 252,63 \\
\hline 450 & & 1,5 & 189,47 \\
\hline 560 & & 0,8 & 100,05 \\
\hline 710 & & 1,0 & 101,02 \\
\hline 900 & & 0,2 & 24,15 \\
\hline 1120 & & 0,1 & 10,10 \\
\hline 450 & \multirow{5}{*}{450} & 1,2 & 151,55 \\
\hline 560 & & 1,1 & 138,90 \\
\hline 710 & & 0,8 & 100,01 \\
\hline 900 & & 0,5 & 63,10 \\
\hline 1120 & & 0,4 & 50,40 \\
\hline 450 & \multirow{5}{*}{560} & 1,0 & 121,12 \\
\hline 560 & & 0,5 & 60,15 \\
\hline 710 & & 0,4 & 49,95 \\
\hline 900 & & 0,2 & 24,00 \\
\hline 1120 & & 0,1 & 9,55 \\
\hline
\end{tabular}



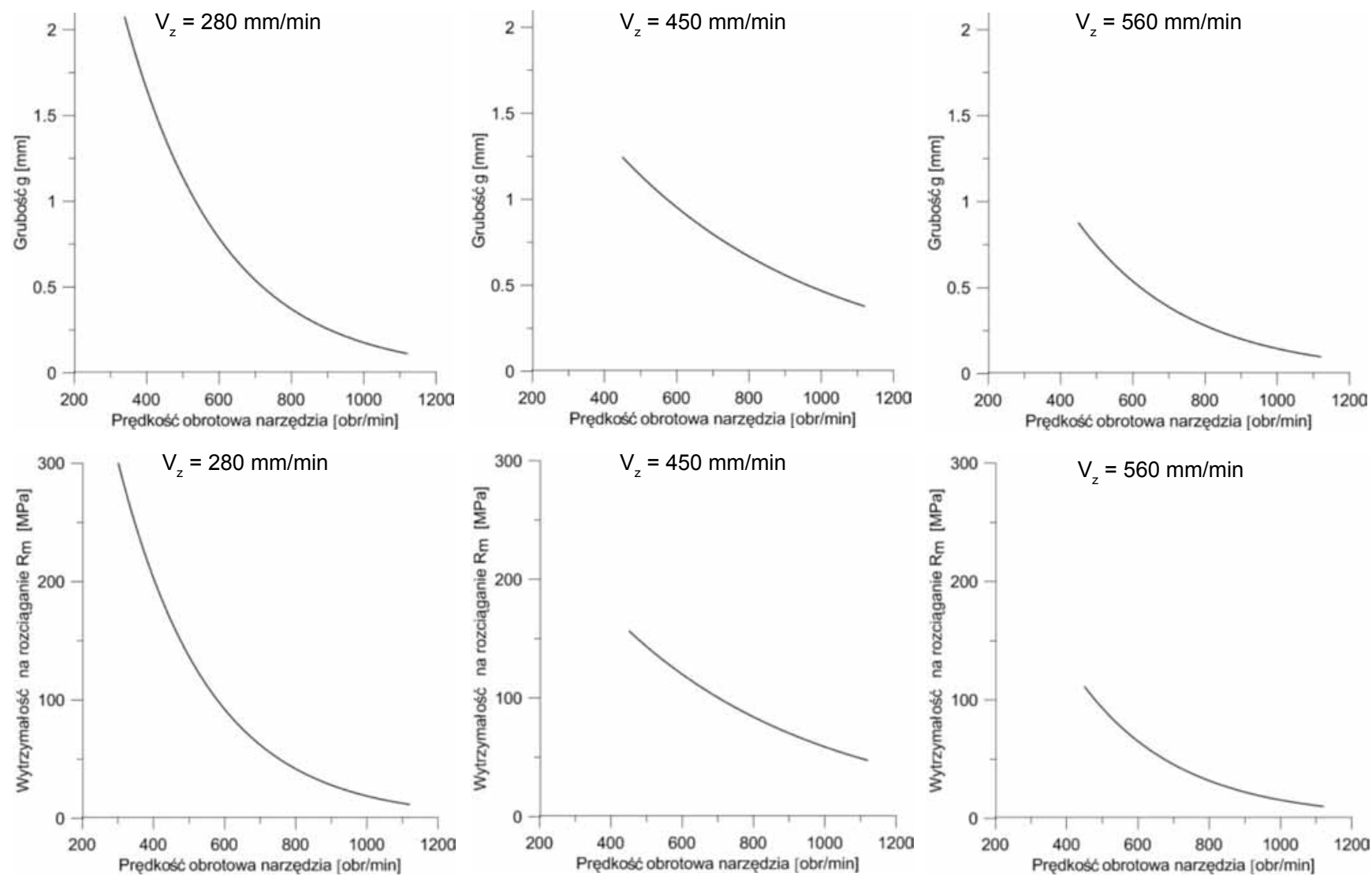

Rys. 8. Przebieg zmian grubości zgrzeiny $g$ i wytrzymałości złączy $R_{m}$ uzyskanych przy różnych parametrach zgrzewania

Fig. 8. Run of the thickness of weld $g$ and the tensile strength $R_{m}$ as a function of the rotational speed obtained for different welding speeds

\section{Zgrzewanie rury z pokrywą specjalnym narzędziem bez trzpienia}

Proces zgrzewania narzędziem bez trzpienia, badany w przypadku zgrzewania blach, zastosowano również do łączenia rury z pokrywą. Schemat ustawienia narzędzia podczas prób technologicznych przedstawiono na rysunku 9. Oś narzędzia ustawiona była w styku łączonych elementów.

Stabilizację warunków zgrzewania po obwodzie rury, wzdłuż całej linii zgrzewania, badano analizując zarejestrowane przebiegi momentu tarcia oraz sił w kierunku zgrzewania, a także temperaturę narzędzia w miejscu jego styku z materiałem zgrzewanym. Dobór parametrów zgrzewania prowadzono pod kątem o selekcji najbardziej stabilnych i powtarzalnych warunków

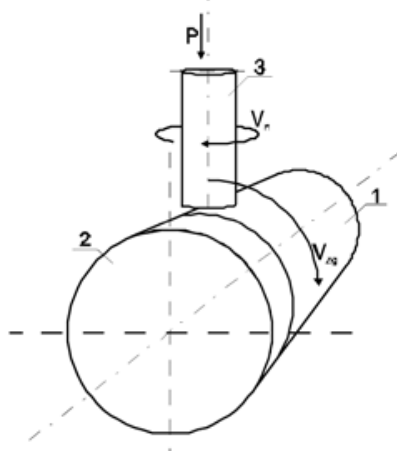

Rys. 9. Schemat procesu zgrzewania tarciowego rury z pokrywą 1 - rura, 2 - pokrywa, 3 - narzędzie; $\mathrm{P}$ - siła docisku narzędzia $v_{n}$ - prędkość obrotowa, obr/min, $\mathrm{v}_{\mathrm{zg}}$ - prędkość zgrzewania (posu$\mathrm{wu}), \mathrm{mm} / \mathrm{min}$

Fig. 9. Scheme of the friction welding process of tube and cover; 1 - tube, 2 - cover, 3 - tool $P$ - friction force, $v_{n}$ - rotational speed, $\mathrm{rpm}, \mathrm{v}_{\mathrm{zg}}-$ welding speed $\mathrm{mm} / \mathrm{min}$
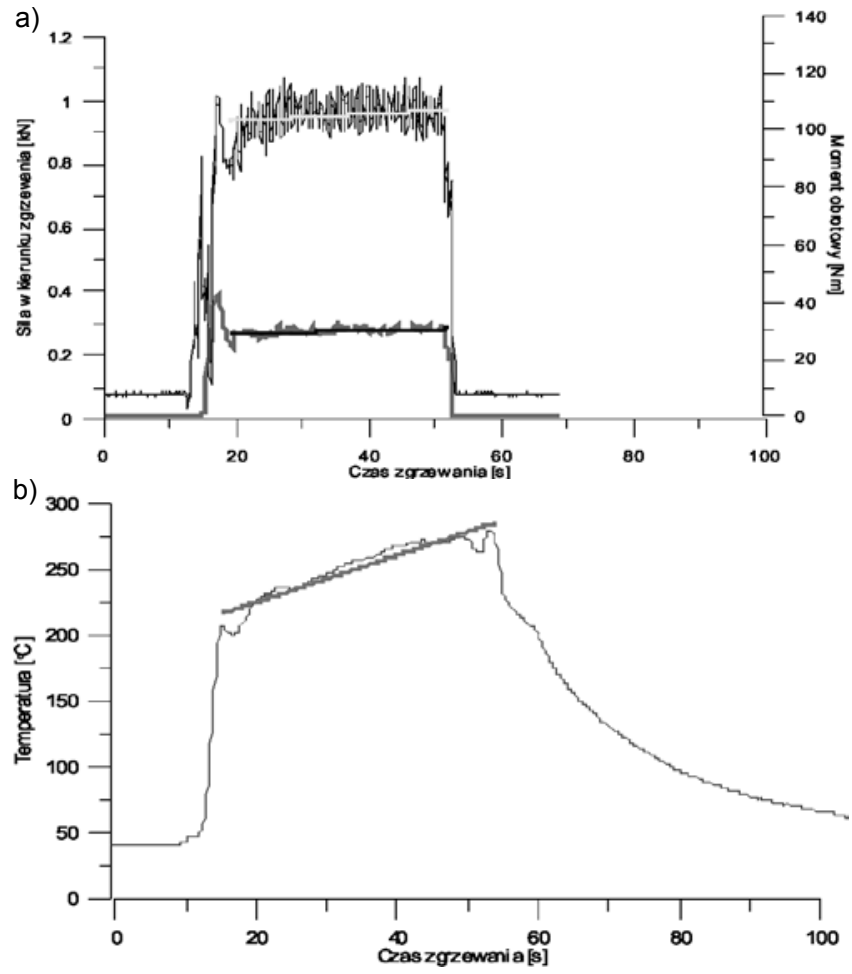

Rys. 10. Przykładowy przebieg zmian sił (a) i temperatury (b) podczas zgrzewania rury z pokrywą z prędkością obrotową narzędzia $1120 \mathrm{obr} / \mathrm{min}$ oraz prędkością liniową zgrzewania $430 \mathrm{~mm} / \mathrm{min}$

Fig. 10. Exemplary run of the force and torque (a), and temperature (b) during welding of the tube and cover with the rotational speed $1120 \mathrm{rpm}$ and the welding speed $430 \mathrm{~mm} / \mathrm{min}$ 

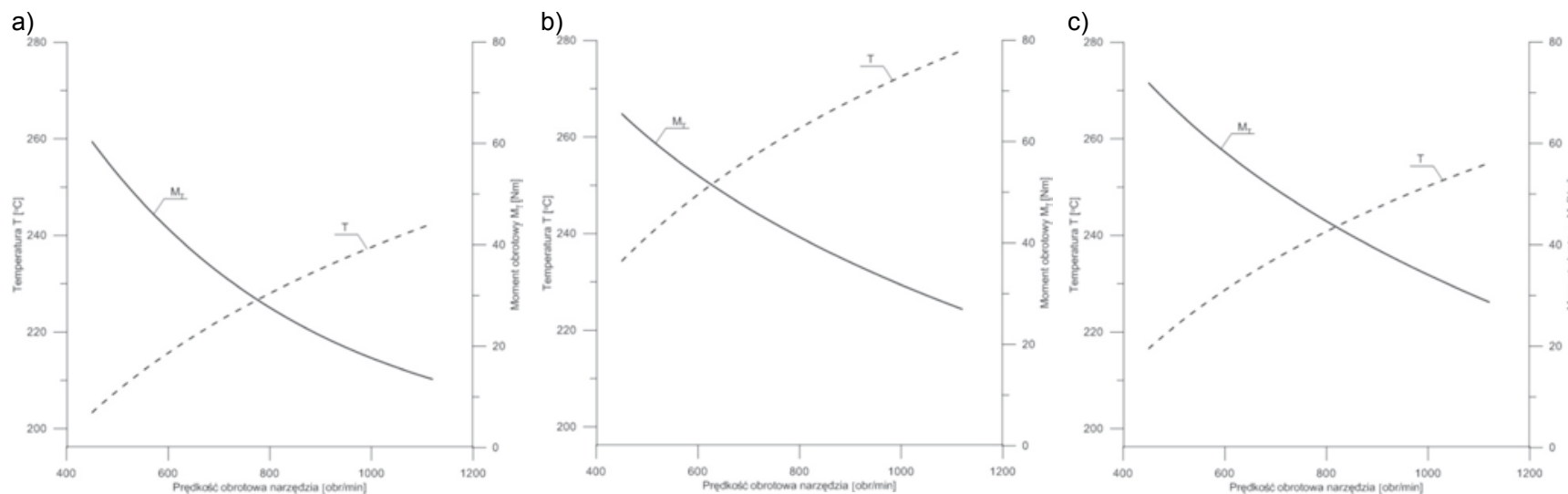

Rys. 11. Zmiana momentu tarcia $\mathrm{M}_{\mathrm{t}} \mathrm{i}$ temperatury T wraz ze zmianą prędkości obrotowej narzędzia dla różnych prędkości liniowych zgrzewania: a) $210 \mathrm{~mm} / \mathrm{min}$, b) $430 \mathrm{~mm} / \mathrm{min}$, c) $540 \mathrm{~mm} / \mathrm{min}$

Fig. 11. Diagram of the friction torque $M_{t}$ and temperature $T$ as a function of the rotational speed for a different welding speeds: a) $210 \mathrm{~mm} / \mathrm{min}$, b) $430 \mathrm{~mm} / \mathrm{min}$, c) $540 \mathrm{~mm} / \mathrm{min}$

nagrzewania i uplastyczniania materiału na całym obwodzie rury. Typowy przebieg momentu tarcia, sił i temperatury przedstawiono na rysunku 10.

Podczas prowadzenia pomiarów zanotowano, że stabilizacja sił i momentów następowała szybko po pierwszej fazie wnikania narzędzia w materiały zgrzewane, natomiast temperatura narzędzia i całego obszaru zgrzewania w całym okresie tarcia rosła. Wyniki pomiarów temperatury i momentu tarcia, zarejestrowane w końcowym obszarze zgrzewania, tuż przed zakończeniem procesu, aproksymowane odpowiednimi funkcjami, przedstawiono na rysunku 11.

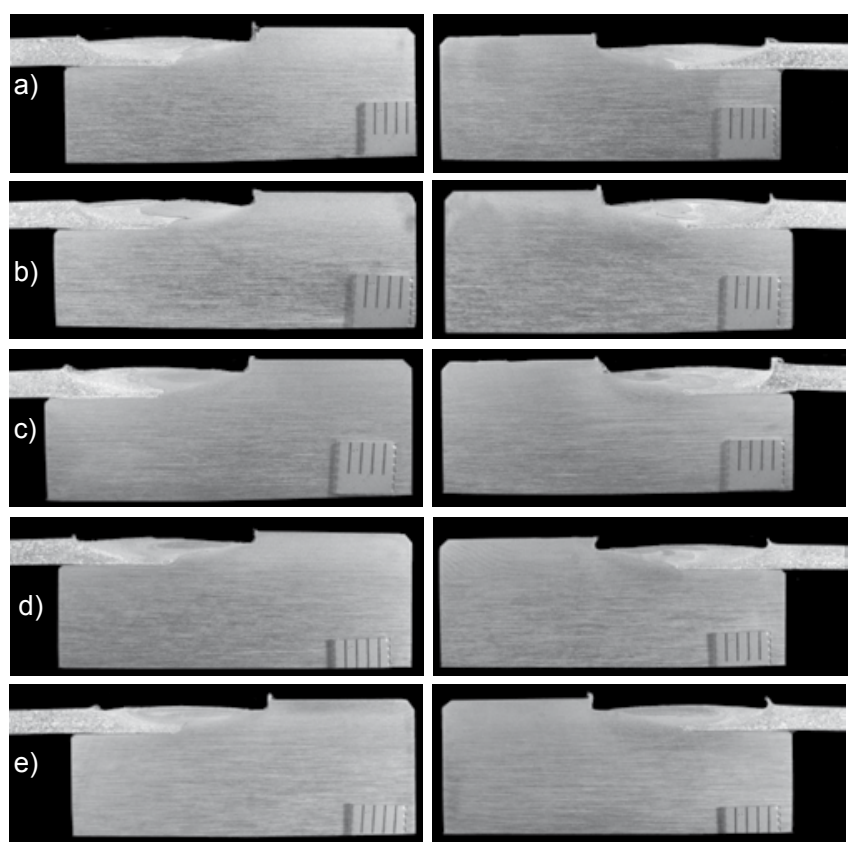

Rys. 12. Makrostruktury złączy wykonanych przy różnych prędkościach obrotowych narzędzia, $v_{z q}=430 \mathrm{~mm} / \mathrm{min}$. Z lewej strony struktury zgrzein na początku linii zgrzewania, z prawej struktury zgrzein na końcu linii: a) $v_{n}=450 \mathrm{obr} / \mathrm{min}$, b) $v_{n}=560 \mathrm{obr} / \mathrm{min}$, c) $v_{n}=900 \mathrm{obr} / \mathrm{min}$, d) $v_{n}=1120 \mathrm{obr} / \mathrm{min}$, e) $v_{n}=1400 \mathrm{obr} / \mathrm{min}$

Fig. 12. Macrostructures of joints made by different rotational speeds, $\mathrm{Vzg}=430 \mathrm{~mm} / \mathrm{min}$. On the left side the weld's structure on the beginning of the process and on the right side the weld's structure at the end of the process are shown: a) $\left.v_{n}=450 \mathrm{rpm}, \mathrm{b}\right) \mathrm{v}_{\mathrm{n}}=560 \mathrm{rpm}$, c) $\left.\left.v_{\mathrm{n}}=900 \mathrm{rpm}, \mathrm{d}\right) \mathrm{v}_{\mathrm{n}}=1120 \mathrm{rpm}, \mathrm{e}\right) \mathrm{v}_{\mathrm{n}}=1400 \mathrm{rpm}$
Jak wynika z badań, dla wszystkich prędkości liniowych zgrzewania wraz ze wzrostem prędkości obrotowej narzędzia moment tarcia gwałtownie spada, natomiast temperatura obszaru zgrzewania wzrasta. Jest to typowe zjawisko obserwowane podczas zgrzewania tarciowego konwencjonalnego i FSW.

Zbadano budowę strukturalną zgrzein wykonanych przy różnej prędkości obrotowej zgrzewania oraz ustalonej, najbardziej korzystnej prędkości liniowej zgrzewania. Prędkość zgrzewania dobrano pod kątem prognozowanej wydajności procesu podczas produkcji. W wyniku prowadzonej analizy danych pomiarowych i po wykonanych wstępnych próbach za najkorzystniejszą uznano prędkość zgrzewania $430 \mathrm{~mm} / \mathrm{min}$, która pozwalała na wykonanie zgrzeiny na całym obwodzie w czasie 0,5 s. Ze względu na obserwowany wzrost temperatury wzdłuż całej linii zgrzewania sprawdzono budowę zgrzeiny na początku procesu i na końcu linii zgrzewania. Wybrane wyniki badań przedstawiono na rysunku 12.

Jakość zgrzewania sprawdzono w próbie ciśnieniowej, na zamkniętej z dwóch stron pokrywami rurze. Próbę ciśnieniową prowadzono do momentu zniszczenia złączy w zgrzeinie, w strefie wpływu ciepła lub zniszczenia materiału rury. Wyniki z próby ciśnieniowej dla elementów zgrzewanych przy różnych prędkościach obrotowych narzędzia wykazały, że dla
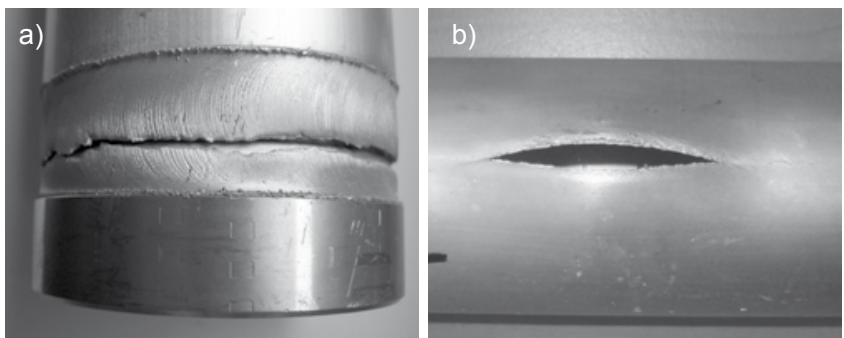

Rys. 13. Przykładowe zdjęcia próbek po próbie ciśnieniowej: a) zniszczenie złącza $\mathrm{w}$ zgrzeinie $\left(v_{n}=1400 \mathrm{obr} / \mathrm{min}, v_{z g}=430\right.$ $\mathrm{mm} / \mathrm{min})$, b) zniszczenie $\mathrm{w}$ materiale rury $\left(v_{n}=450 \mathrm{obr} / \mathrm{min}\right.$, $\mathrm{V}_{\mathrm{zg}}=430 \mathrm{~mm} / \mathrm{min}$ )

Fig. 13. Exemplary photographs of the test pieces after the pressure test: a) failure in the weld $\left(v_{n}=1400 \mathrm{rpm}, V_{z g}=430 \mathrm{~mm} / \mathrm{min}\right)$, b) failure in the material of tube $\left(v_{n}=450 \mathrm{rpm}, v_{z g} \stackrel{2 g}{=} 430 \mathrm{~mm} / \mathrm{min}\right)$

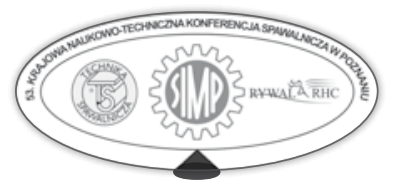


wszystkich warunków zgrzewania szczelność złącza jest gwarantowana do ciśnienia próbnego $10 \mathrm{MPa}$.

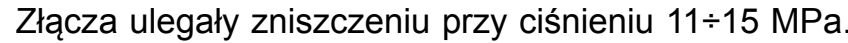
Przykładowe zdjęcia próbek poddanych badaniom ciśnieniowym przedstawiono na rysunku 13. Największą wytrzymałość wykazywały złącza wykonane przy najmniejszej prędkości obrotowej narzędzia.

\section{Analiza wyników}

W artykule zbadano możliwość wykonywania złączy zgrzewanych tarciowo na elementach z niespawalnego stopu aluminium EN AW 2017A. Jest to materiał cechujący się dużą wrażliwością na temperaturę podczas procesów spawalniczych. Kruche struktury powstałe w czasie nagrzewania tego stopu podczas spawania lub zgrzewania obniżają jakość złączy i nie pozwalają na stosowanie znanych technik spawalniczych w procesie produkcyjnym, zwłaszcza odpowiedzialnych wyrobów. Z tego powodu, opracowując warunki zgrzewania elementów wykonanych z tego materiału, zwrócono uwagę na poznanie warunków cieplnych procesu nagrzewania tarciowego i przeanalizowano ich wpływ na budowę zgrzeiny.

Z badań wynika, że metodą FSW można uzyskać złącza o wysokiej i powtarzalnej jakości, w szerokim zakresie parametrów zgrzewania. Złącza charakteryzują się typową dla FSW budową strukturalną i mają wysokie właściwości wytrzymałościowe. Trudnością, wiążącą się z procesem FSW, jest pozostały po procesie otwór technologiczny - ślad po wycofywanym narzędziu, znacznie obniżający wytrzymałość tego odcinka zgrzeiny obwodowej. Otwór technologiczny na końcu zgrzeiny wykonywanej na pobocznicy elementów walcowych poważnie ogranicza możliwość zastosowania produkcyjnego tej metody.

Wstępne wyniki badan zgrzewania blach nowo opracowaną metodą z narzędziem, na powierzchni roboczej którego nacięto rowek w postaci spirali, wykazały znaczny wpływ warunków zgrzewania na jakość złączy. Wytrzymałość złączy zależała głównie od prędkości obrotowej narzędzia oraz w mniejszym stopniu od prędkości zgrzewania. Największą wytrzymałość uzyskują złącza wykonywane przy niskiej prędkości obrotowej - 450 obr/min. Wraz ze wzrostem prędkości obrotowej wytrzymałość gwałtownie spada. Zależność ta występuje dla przebadanych prędkości zgrzewania: 280, 450 i $560 \mathrm{~mm} / \mathrm{min}$ (rys. 8). Wytrzymałość złącza wiąże się z budową strukturalną zgrzeiny. Stwierdzono, analizując makrostruktury zgrzein wykonanych w różnych warunkach prowadzenia procesu zgrzewania, że im mniejsza jest prędkość obrotowa narzędzia, tym większa jest głębokość jego oddziaływania i związana z tym grubość zgrzeiny g (tabl. III). Przy małej prędkości obrotowej narzędzia grubość zgrzeiny sięga grubości zgrzewanych blach, natomiast przy maksymalnej prędkości obrotowej uwzględnionej w badaniach (1120 obr/min) stanowi jedynie 5\% grubości blach.
Korzystając z wyników badań zgrzewania blach dobrano warunki zgrzewania elementów rurowych, gwarantujące uzyskanie odpowiednich właściwości złącza zgrzewanego i tym samym właściwe parametry jego eksploatacji. Opracowano konstrukcję pokrywy przydatną do zgrzewania tarciowego (rys. 2) oraz narzędzie do zgrzewania (tabl. I). Przeprowadzono cykl badań zgrzewania tarciowego z zastosowaniem narzędzia z naciętą spiralą na płaskiej powierzchni roboczej.

Analizując proces zgrzewania od strony warunków cieplnych tarcia stwierdzono, że przy najmniejszych prędkościach obrotowych narzędzia, korzystnych z punktu widzenia wytrzymałości złącza, temperatura procesu jest najniższa i wzrasta wraz ze wzrostem prędkości obrotowej tarcia oraz prędkości zgrzewania. Moment tarcia zaś spada wraz ze wzrostem prędkości obrotowej narzędzia (rys. 11). Można stwierdzić, że przy wzrastającej prędkości tarcia proces odkształcania materiału siłami tarcia odbywa się w coraz wyższej temperaturze, przy spadającej wytrzymałości i objętości odkształcanego materiału. Z przeprowadzonych badań i analiz wynika, że aby uzyskać złącze o odpowiedniej jakości, należy prowadzić proces zgrzewania przy stosunkowo niskiej prędkości tarcia, czyli niskiej prędkości obrotowej i małej prędkości zgrzewania, wówczas temperatura procesu będzie najniższa, a zgrzeina będzie rozbudowana na wystarczającą głębokość. Odrębny problem stanowi wzrost temperatury i kumulowanie się ciepła wzdłuż linii zgrzewania rury, obserwowany we wszystkich przebadanych warunkach procesu (rys. 10). Jednak jak stwierdzono, nie wpływa on istotnie na budowę strukturalną zgrzeiny. Przy odpowiednim zestawie parametrów ruchu narzędzia uzyskano zgrzeinę ciągłą o wystarczającej grubości i szczelności wzdłuż całej linii zgrzewania (rys. 12). Wpływ kumulowanego się ciepła w badanej konfiguracji elementów na przebieg procesu zgrzewania jest w dalszym ciągu badany.

Nowa technologia zgrzewania tarciowego, wykorzystująca specjalnie ukształtowane narzędzie, odpowiednio ustawione podczas procesu zgrzewania względem osi elementów (rys. 3a), spełniła wszystkie warunki, jakie musi spełniać technologia przewidziana do zastosowania produkcyjnego. Średnicę narzędzia w części roboczej ustalono na 14 lub $15 \mathrm{~mm}$, w zależności od sztywności i mocy urządzenia do zgrzewania i wydajności procesu. Dla obu narzędzi uzyskano w Instytucie Spawalnictwa odpowiednią jakość zgrzeiny. Najkorzystniejsza z punktu widzenia jakości i wydajności procesu okazała się prędkość zgrzewania $430 \mathrm{~mm} / \mathrm{min}$. Przy tej prędkości czas zgrzewania całego obwodu wynosi ok. 0,5 s, co gwarantuje wystarczającą płynność produkcji.

Przy ustalonych warunkach prowadzenia procesu zgrzeina na całym obwodzie zgrzewania ma grubość ok. $2 \mathrm{~mm}$ i stanowi szczelne połączenie pokrywy z rurą (rys. 13). Ocenę wytrzymałości tak uzyskanego złącza prowadzono głównie na podstawie badań 
szczelności w próbie ciśnieniowej. Wszystkie złącza uzyskiwały wystarczającą wytrzymałość, nie ulegając zniszczeniu przy wymaganym ciśnieniu próbnym $10 \mathrm{MPa}$. W zależności od warunków zgrzewania złą-

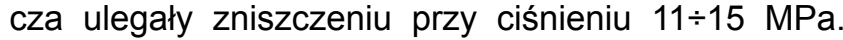
Elementy wykonywane przy najmniejszej prędkości zgrzewania ulegały zniszczeniu przez rozerwanie rury, przy zachowaniu spójności zgrzein. Jak sprawdzono, obróbka skrawaniem powierzchni prawidłowo wykonanych złączy nie obniża jakości połączeń poniżej wymaganego poziomu. Głębokość skrawania nie może być jednak większa niż $0,5 \mathrm{~mm}$.

\title{
Wnioski
}

Szczelne połączenie pokrywy z rurą, wykonane z niespawalnego stopu aluminium EN AW 2017A, można uzyskać metodą zgrzewania tarciowego z niezużywającym się narzędziem trącym.

Najlepszą jakość połączenia uzyskuje się przy stosunkowo niewielkich prędkościach obrotowych narzędzia i małej prędkości zgrzewania.

Wzrost prędkości obrotowej tarcia powoduje spadek głębokości oddziaływania narzędzia i zmniejszenie grubości zgrzeiny.

Temperatura obszaru zgrzewania wzrasta wraz ze wzrostem prędkości tarcia.
Temperatura obszaru zgrzewania wzrasta podczas procesu wzdłuż linii zgrzewania na skutek kumulowania się ciepła w materiale rury i pokrywy. Wzrost ten nie wpływa jednak na budowę strukturalną zgrzeiny.

Narzędzie bez dodatkowego trzpienia może być zastosowane do zgrzewania blach i płyt. Głębokość oddziaływania narzędzia, jak i związane z tym grubość zgrzeiny i jej nośność zależą od prędkości zgrzewania. Użyteczne połączenia można uzyskać dla bardzo niskich wydajności procesu.

\section{Literatura}

[1] Thomas W.M. Friction Stir Butt Welding. Int. Patent Application. PCT/GB92/02203. 1991.

[2] Mroczka K., Dutkiewicz J., Pietras A.: Characterization of friction stir welds of 6013 and $6013 / 2017 \mathrm{~A}$ aluminium alloy sheets. Inżynieria Materiałowa, $31 \mathrm{nr}$ 3/ 2010, 586-589.

[3] Węglowski M.S., Pietras A., Węglowska A.: Effect of weIding parameters on mechanical and microstructural properties of Al 2024 joints produced by friction stir welding. Journal of Kones Powertrain and Transport, vol. 19, nr 1/2009, s. $523-532$.
[4] Guohong LUAN., Guang LI., Weibing WANG, Ju KANG.: The Fundamental Research of the Friction Flow Welding. The 8th international Friction Stir Welding Symposium, Germany, 18-20 May 2010.

[5] Opracowanie i wdrożenie technologii zgrzewania obwodowego tarciowego głowicy z tuleją siłownika pneumatycznego. Praca Badawcza dla REWA Sp z o.o. nr B-182/2009.

[6] Zgłoszenie do UP RP nr P.390268. Sposób zgrzewania tarciowego doczołowego blaszanych zaślepek z korpusem chłodnicy. Oddział w Opolu

\author{
informuje o organizacji
}

\section{KONFERENCJI SPAWALNICZEJ „SPAWANIE W ENERGETYCE”}

w dniach od 24 do 26 kwietnia 2012 r. w Ośrodku Ziemowit w Jarnoltówku

\author{
- sesje referatowe \\ - wystawy techniczne \\ - imprezy towarzyszące \\ Wszystkich zainteresowanych udziałem w konferencji zapraszamy do skontaktowania się z Polskim \\ Towarzystwem Spawalniczym - Oddział w Opolu.
}

Dodatkowe informacje: Pocica Anna, tel. 487740062 51, e-mail: a.pocica@po.opole.pl Derwich Tomasz, tel. 487740192 95, e-mail: tomasz.derwich@esab.pl

Korespondencję prosimy kierować pod adresem: POLSKIE TOWARZYSTWO SPAWALNICZE - ODDZIA $Ł$ W OPOLU ul. A. Struga 10, 45-073 OPOLE (fax: 487740192 01) 